Covered in: Web of Science (WOS); EBSCO; ERIH+; Google Scholar; Index Copernicus; Ideas RePeC; Econpapers; Socionet; CEEOL; Ulrich ProQuest; Cabell, Journalseek; Scipio; Philpapers; SHERPA/RoMEO repositories; KVK;

WorldCat; CrossRef; CrossCheck

2021, Volume 13, Issue 3, pages: 134-150 | https://doi.org/10.18662/rrem/13.3/444

\section{Training of Remotely Piloted Aircraft Operators for Border Surveillance in Ukraine based on the European Union Standards}

\author{
Ivan KATERYNCHUK'1, \\ Andrii BALENDR ${ }^{2}$, \\ Oksana KOMARNY'TSKA ${ }^{3}$, \\ Oleksandra ISLAMOVA 4 , \\ Ilona ORDYNSKA 5 , \\ Tetiana CHUBINA ${ }^{6}$
}

${ }^{1}$ Doctor of Sciences in Technology, Professor, Engineering Faculty, Bohdan Khmelnytskyi National Academy of the State Border Guard Service of Ukraine, kater_is@ukr.net, orcid.org/0000-00028634-0916

${ }^{2}$ Doctor of Sciences in Pedagogy, Associate professor, Foreign Languages Department, Bohdan Khmelnytskyi National Academy of the State Border Guard Service of Ukraine, Khmelnytskyi, Ukraine, drbalen@i.ua, orcid.org/00000003-4610-2830

${ }^{3} \mathrm{PhD}$ in Philology, Associate professor, Foreign Languages Department, Bohdan Khmelnytskyi National Academy of the State Border Guard Service of Ukraine, Khmelnytskyi, Ukraine, o.i.komarnytska@gmail.com, orcid.org/0000-0001-9156-4482

${ }^{4} \mathrm{PhD}$ in Philosophy, Senior Lecturer, Foreign Languages Department, Bohdan Khmelnytskyi National Academy of the State Border Guard Service of Ukraine, Khmelnytskyi, Ukraine, a.islamova90@gmail.com, orcid.org/00000002-2102-7363

${ }^{5} \mathrm{PhD}$ in Philology, Senior Lecturer, Foreign Languages Department, Bohdan
Abstract: The study reveals the theoretical and practical approaches to building of an all-European training strategy for remotely piloted aircraft systems (RPAS) operators to increase their interoperability in the European Union countries and Ukraine. Nowadays, the border guard agencies both in EU and Ukraine have developed their national courses and training programs related to training of RPAS operators, however, the proposed in this study common approach is based on the Sectoral Qualification Framework in the field of border protection and Common Core Curriculum for border guards in EU and is aimed at expanding the use of small RPAS for a specific task of protecting the border sectors of various types (land, sea, air) in accordance with the Concept of European Integrated Border Management. The research was carried out in the frames of the Grant Program of the European Agency for Border and Coast Protection Frontex "The use of RPAS for border protection - tactics, guidelines, best practices". The study covers the analysis of the theory, market solutions, takes into account practical border protection experience, which resulted in creation of a common curricula for operators of RPAS in the specific sphere - surveillance of the state borders. The developed training course for RPAS operators provides an opportunity to train external crews of unmanned aerial vehicles, which will best meet the objectives and peculiar needs of the state border protection agencies of the European Union and Ukraine. The readiness of future RPAS operators to perform professional duties on border surveillance was diagnosed according to cognitive (knowledge formation) and operational (skills and abilities formation) criteria. Comparison of the values of these criteria before and after the formative stage of the experiment shows that the experimental measures for the application of best European practices in the training of RPAS operators have positively affected the quality of their training. The results of the study will help strengthen the state border security within the European context of border guarding by means of increasing the level of interoperability of RPAS operators in the EU countries and Ukraine.

Keywords: remotely piloted aircraft systems, professional training, border guards, European Union, border surveillance.

How to cite: Katerynchuk, I., Balendr, A., Komarnytska, O., Islamova, O., Ordynska, I., \& Chubina, T. (2021). Training of Remotely Piloted Aircraft Operators for Border Surveillance 
Khmelnytskyi National Academy of the State Border Guard Service of Ukraine, Khmelnytskyi, Ukraine,

ilonaordynska@ukr.net,orcid.org/00000001-9673-8576

${ }^{6}$ Doctor of Sciences in History, Professor, Social Sciences Department, Cherkasy

Heroes of Chernobyl Fire Safety Institute of the National University of Civil Defense of Ukraine,chubina@ukr.net,orcid.org/ 0000-0002-9383-3604 in Ukraine based on the European Union Standards. Revista

Romaneasca pentru Educatie Multidimensionala, 13(3), 134-150. https://doi.org/10.18662/rrem/13.3/444 


\section{Introduction}

The use of RPAS in border protection is constantly expanding. Firstly, it is a cost-effective solution, and secondly - the most effective in comparison to the use of other means of patrolling, for example, manned aircraft, which is often cost-ineffective to use, because of the small areas of controlled territory. Modern low-cost RPAS have adequate tactical and technical characteristics, allowing to strengthen control of even the most remote and inaccessible border areas. Due to the improved maximum payload weight, RPAS operators in real-time can receive accurate, highquality imagery of patrolled areas, detect and recognize potential border violators. At the same time, often in the areas within the protected border sectors, water-bodies, agricultural crops are present, which are convenient for smuggling, illegal migration, and preparation of terrorist acts. The use of RPAS allows to patrol the borders both at close and long distances with the transmission of photo and video information on-line at any time of the day, under different weather and climatic conditions. RPAS not only detect such risks, but also recognize the violators and automobile number plates. RPAS can provide continuous gathering and transmission of the information at the border in both automatic and semi-automatic modes. Due to the system of active tracking, RPAS, having detected a potentially hostile object, fixes its location, reports the coordinates to the ground control station, automatically tracks and transmits information about its actions. Such patrolling is possible in any terrain, even the most remote and sparsely populated border areas. The use of unmanned aerial vehicles for border protection, detection and prevention of cross-border crimes is still evolving. However, there is no doubt that the development of technologies in the field of RPAS, optoelectronic sensors and artificial intelligence provides new opportunities for effective border control.

There are two different types of Unmanned Aerial Vehicles (UAVs): drones and RPAS. Both drones and RPAS are pilotless, but drones are programmed for autonomous flight. RPAS are actively flown remotely by a ground control operator. UAV is defined as a powered aerial vehicle that does not carry a human operator, uses aerodynamic forces to provide lift, can fly autonomously or be piloted remotely, can be expendable or recoverable, and can carry lethal or nonlethal payloads (Dictionary of Military and Associated Terms, 2001). 
Training of Remotely Piloted Aircraft Operators for Border Surveillance in ... Ivan KATERYNCHUK, et al.

According to NATO STANAG 4670 Guidance for the Training of Unmanned Aircraft Systems Operators classification of UAVs can be distinguished as follows (NATO STANAG 4670, 2014):

\begin{tabular}{|c|c|c|c|c|c|c|}
\hline \multicolumn{7}{|c|}{ NATO UAV CLASSIFICATION } \\
\hline Class & Category & $\begin{array}{c}\text { Normal } \\
\text { Employment }\end{array}$ & $\begin{array}{c}\text { Normal } \\
\text { Operating } \\
\text { Attitude }\end{array}$ & $\begin{array}{l}\text { Normal } \\
\text { Mission } \\
\text { Radius }\end{array}$ & $\begin{array}{c}\text { Primary } \\
\text { Supported } \\
\text { Commander }\end{array}$ & $\begin{array}{l}\text { Example } \\
\text { Platform }\end{array}$ \\
\hline \multirow{3}{*}{$\begin{array}{c}\text { Class } \\
\text { III } \\
(>600 \\
\mathrm{kg})\end{array}$} & $\begin{array}{l}\text { Strike / } \\
\text { Combat }\end{array}$ & Strategic / National & $\begin{array}{c}\text { Up to } \\
65.000 \mathrm{fl}\end{array}$ & $\begin{array}{c}\text { Unlimited } \\
\text { (BLOS) }\end{array}$ & Theatre & Reaper \\
\hline & HALE & Strategic/National & $\begin{array}{c}\text { Up to } \\
65.000 \mathrm{fl}\end{array}$ & $\begin{array}{c}\text { Unlimited } \\
\text { (BLOS) }\end{array}$ & Theatre & $\begin{array}{l}\text { Global } \\
\text { Hawk }\end{array}$ \\
\hline & MALE & Operational/Theatre & $\begin{array}{c}\text { Up to } \\
45.000 \mathrm{fl}\end{array}$ & $\begin{array}{c}\text { Unlimited } \\
\text { (BLOS) }\end{array}$ & JTF & Heron \\
\hline \multirow{2}{*}{$\begin{array}{c}\text { Class } \\
\text { II } \\
(150 \\
\mathrm{kg}- \\
600 \\
\mathrm{~kg}) \\
\end{array}$} & Tactical & $\begin{array}{c}\text { Tactical } \\
\text { Formation }\end{array}$ & $\begin{array}{c}\text { Up to } \\
18.000 \mathrm{ft} \\
\end{array}$ & $\begin{array}{c}200 \mathrm{~km} \\
(\mathrm{LOS})\end{array}$ & Brigade & $\begin{array}{c}\text { Hermes } \\
450 \\
\end{array}$ \\
\hline & $\begin{array}{c}\text { Small } \\
(>15 \mathrm{~kg})\end{array}$ & Tactical Unit & $\begin{array}{l}\text { Up to } \\
5,000 \mathrm{ft}\end{array}$ & $\begin{array}{l}50 \mathrm{~km} \\
(\mathrm{LOS})\end{array}$ & $\begin{array}{l}\text { Battalion. } \\
\text { Regiment }\end{array}$ & $\begin{array}{l}\text { Scan } \\
\text { Eagle }\end{array}$ \\
\hline \multirow[t]{2}{*}{$\begin{array}{c}\text { Class I } \\
(<150 \\
\mathrm{kg})\end{array}$} & $\begin{array}{c}\text { Mini }(<15 \\
\mathrm{kg})\end{array}$ & $\begin{array}{l}\text { Tactical Sub-unit } \\
\text { (manual launch) }\end{array}$ & $\begin{array}{l}\text { Up to } \\
3.000 \mathrm{ft}\end{array}$ & $\begin{array}{c}\text { Up to } 25 \\
\mathrm{~km} \\
\text { (LOS) } \\
\end{array}$ & $\begin{array}{l}\text { Company, } \\
\text { Squad }\end{array}$ & Skylark \\
\hline & $\begin{array}{l}\text { Micro } \\
(<66 \mathrm{~J})\end{array}$ & $\begin{array}{l}\text { Tactical Subunit } \\
\text { (manual launch) }\end{array}$ & $\begin{array}{l}\text { Up to } \\
200 \mathrm{ft} \\
\text { AGL }\end{array}$ & $\begin{array}{c}\text { Up to } 5 \\
\mathrm{~km} \\
\text { (LOS) }\end{array}$ & $\begin{array}{l}\text { Platoon, } \\
\text { Squad }\end{array}$ & $\begin{array}{c}\text { Black } \\
\text { Widow }\end{array}$ \\
\hline
\end{tabular}

Figure 1. UAV Classification according to NATO STANAG 4670 (Source: NATO STANAG 4670, 2014)

The range of RPAS is a significant asset when compared to border guard agents on patrol or stationary surveillance equipment. If an illegal border entrant attempts to transit through dense woods or mountainous terrain, RPAS would have a greater chance of tracking the violator with thermal detection sensors than the stationary video equipment which is often used on the borders (Haddal \& Gertler, 2010).

Nowadays the RPAS deployment in border surveillance at EU level is a part of the policy that aims at strengthening the surveillance of external EU borders as a tool to control irregular migration. Within EU Border and Coast Guard Agency Frontex has been acting efficiently at national and European level, coordinating and cooperating with the third countries in order to detect, identify, track and intercept persons attempting to enter the EU illegally outside border crossing points. RPAS deployment is a part of 
the process that is consolidating a shift in border surveillance from an emergency-driven policy to an intelligence and risk management approach of border surveillance (Marin, 2016a).

Regardless of whether the RPAS will be operated by an experienced border guard or a young cadet, it will be necessary to take a basic operator course, which includes the basics of RPAS operation, taking into account that the RPAS will be used for border control and other law enforcement and search and rescue operations. A wide range of scientific works in this field is devoted to the study of RPAS application problems. Most of them concern the issues of technical equipment of RPAS and ways of their effective application. So, the problems of effective accomplishing of the state security tasks using RPAS of various types was conducted in the units of the State Border Guard Service of Ukraine. It was concluded that the role of RPAS that can be used for the state border protection tasks is growing (Mykytiuk, 2018). Also, the issues of rational application of optoelectronic surveillance systems, including those based on RPAS were studied in the context of monitoring the situation at the state border. A comprehensive research of various factors influencing the identification of targets was carried out (Katerynchuk et al., 2016). The effectiveness of RPAS was evaluated depending on the type of control systems, terrain, altitude and range (Katerynchuk et al., 2018).

Given the above, the problem of training highly qualified RPAS operators has become a key one for the border guard agencies both in Ukraine and EU countries (Balendr et al., 2019). In the EU and Ukraine special courses related to the training of RPAS operators were elaborated: RPAS operator training program of the Main Training Centre for Personnel of the State Border Guard Service of Ukraine (Combat Coordination Program of Air Reconnaissance Units of Border Protection Bodies (RPAS quadcopter type); Combat Coordination Program of Air Reconnaissance Units of Border Protection Bodies (aircraft type).

Nevertheless, the problem of interoperability has emerged as different agencies from the EU side and the State Border Guard Service of Ukraine actually guarding one border sector, experienced the necessity to harmonize and share their know-how of the RPAS technology utilizing (Interoperability Assessment Program Study, 2015). Therefore, the Grant Program of the Frontex Agency "The use of RPAS for border protection tactics, guidelines, best practices" based on the analysis of the theory, market solutions and practical border protection experience was organized and conducted, within which the effectiveness of curricula for operators and 
managers of unmanned aerial vehicles monitoring the state borders was thoroughly evaluated.

The study has contributed to the improvement of the Lithuanian and Ukrainian border guards' cooperation immensely. The partnership of Lithuanian and Ukrainian State Border Guard Services has proved to be effective and achieved all the goals of the current project. In the future both training institutions will use the newly established procedures and plans based on the present project implementation experience. Furthermore, the study has significantly enhanced the skills of the Lithuanian and Ukrainian border guards in ensuring safe and well-functioning EU external border security system. In order to ensure a "high and uniform level of control" at the external borders (Regulation EU 1896, 2019), border guard RPAS operators and managers who will be trained according to the designed curricula, will be ready to be deployed in Frontex Joint operations.

The aim of the article is to study the effectiveness of the RPAS operators training for the border surveillance based on the European Union border guard educational standards.

\section{Materials and Methods}

To achieve the goal of the study, there were used such methods: general scientific methods, as well as special theoretical, empirical and statistical methods. The theoretical ones: analysis, synthesis, comparison - to determine the state of the research problem coverage in theory and practice of professional education; systematization, modeling - to clarify the key concepts of the research, justification of the possibility to apply European practices in the professional training of Ukrainian RPAS operators. Quantitative data were obtained through the use of empirical methods, such as: interviews, oral and written interviews, questionnaires, testing, the method of expert evaluation, the method of independent characteristics, the Stating and Formative stages of the pedagogical experiment. Before starting the organization of the experimental work, the composition of the participants of the experiment was determined, the calculation of the sample was performed according to the formula of the $5 \%$ marginal error of representativeness:

$$
n=\frac{1}{0,0025+1 / N}
$$

$\mathrm{N}$ - the volume of the general population;

$\mathrm{n}-$ the size of the sample. 
The total number of participants at the formative stage of the experiment was 99 cadets who attended training courses for RPAS operators at the Main Center for training personnel of the SBGSU (Orshanets, Ukraine). The formative stage of the pedagogical experiment included three stages: preparatory, basic and final. At the preparatory stage from September 2018 to August 2019, the goals and objectives of the formative stage of the experiment were specified, the composition of the control (CG) and experimental (EG) groups was determined, and the incoming control of the training of future specialists in RPAS operation was organized. The CG included 48 students, and the EG - 51 students.

At the main stage of the formative stage of the experiment from September 2019 to December 2019, the educational process of the future RPAS operators of the EG was based on the experimental course "RPAS Operator Course for Border Control". At the final stage, from January 2020 to April 2020, the state of readiness of future RPAS operators for professional activity was diagnosed according to certain criteria (cognitive and operational) and their indicators.

\section{Results of Research}

\subsection{All-European Course for the RPAS Operators Training for Border Surveillance}

Within the framework of cooperation of the State Border Guard Service of Ukraine, the State Border Guard Service of Lithuania and the European Border and Coast Guard Agency FRONTEX, united under the mentioned Grant Program in the period from April to November 2019, a project was conducted to study the training of RPAS operators in the sphere of the state border surveillance system.

The following issues have been considered in the framework of the grant: tasks of the state border protection units requiring the use of RPAS; Market research and key RPAS characteristics; application of unmanned aerial technologies in border surveillance: European experience of organization of flights for the state border protection; basics of flight physics and aerodynamics; flight control; basic flight modes; meteorological conditions; telemetry data processing. Based on the results of the tests, recommendations on the best tactics of border protection using RPAS have been developed.

One of the main advantages of this project is that it was based on practical tests, as well as on the operational experience of border guards and RPAS operators in various fields of application (commercial, law 
enforcement and military). This study was an important addition to the study of FRONTEX airplanes remote control systems, which has differences in time and technological progress. RPAS and related equipment were purchased to obtain test results and videos. The use of experience of external experts and its combination with border guarding tasks and operational environment, tactics and training materials were tested in the field under the same conditions.

The training course regards basic functions and typical situations covering the surveillance of "green" border, search and rescue operations using RPAS, namely:

- the state border line surveillance;

- air inspection of the border line in order to prevent illegal change of its passage, establishment of signs of destruction or movement of elements of border signs;

- control over the condition of border clearings, bridges, crossings, dams, water passes, etc., observance of the procedure for carrying out industrial and other activities at the state border;

- inspection of the state of integrity and efficiency of engineering structures, barriers and control means, identification of signs of their overcoming, destruction or other signs of illegal activity at the state border;

- inspection of the established procedure for keeping small vessels, other vessels at the bases, compliance with the procedure for industrial, research and other economic activities on the coast and in border water bodies;

- timely detection of signs of unauthorized release and navigation of vessels in border water bodies, approach to the shore of warships and nonmilitary vessels, small and other vessels, boarding or disembarking from them, loading or unloading of cargo;

- surveillance of the area, the territory of border crossing points and the adjacent area and areas of probable illegal activity at the state border; observation and tracking of foreign vehicles;

- detection of illegal activity, movement of violators in the area of responsibility etc. 
Table 1. Profile of the all-European Curriculum "RPAS Operator Course for Border Control”

(source: authors)

\section{Course Profile: RPAS OPERATOR COURSE FOR BORDER CONTROL}

Aim of the course: This course is designed for the RPAS operators in order to enhance capacity of using RPAS for border control, thereby strengthening the EU Member States border security.

Constraints: (Time, financial resources, instructors, facilities, location, equipment, to be accredited at a specific level etc.)

\section{Time}

Independent learning phase (ILP) - 16 hours

Contact learning phase CLP - 40 hours

\section{Financial resources}

National border guard authorities

Participants - learners up to 16

Border guards working in border surveillance

Instructors min 2 (recommended 1 instructor per 4 learners for practical part)

Requirements for instructors: knowledge of the material of this course, the ability and recent experience to use RPAS in various tasks of border protection.

\section{Facilities}

Meeting room equipped with laptop, projector, screen for presentations, speakers, flipchart/whiteboard and internet connection (with LAN/Wi-Fi capability); availability of the RPAS to perform practical exercises; radios; computers with software (RPAS flight simulator).

\section{Location}

Border Guard training institutions, Border Guard Divisions

\section{Target group requirements:}

BGs with min. 1 year of experience of performing border surveillance and detecting cross-border crimes. This course will provide them with necessary knowledge, skills and competences to manage cases at external EU borders while patrolling with the use of RPAS.

\section{Entry requirements:}

Border guards qualified in border surveillance tasks; border guards who have completed basic BG training; good general command of English language (minimum B1 or equivalent); possible medical examination; possess basic knowledge of international instruments concerning respect for Fundamental Rights of all people.

The research conducted made it possible to define the key topics of the RPAS operators' course, namely:

1) Types of RPAS used for border control;

2) Overview of main features and technical characteristics of RPAS (Flight duration, Payload and sensors, Reliability and portability, Ease of use and safety, Operating conditions, Ground control station, Data processing software); 
3) RPAS classification by airframe and propulsion (Fixed-wing, piston engines powered RPAS, Fixed-wing, electrical engine powered RPAS, Multicopters, Helicopters, Balloons);

4) Sensors (Daylight cameras: Optical RGB cameras based on FPV technology, RGB cameras: block and embedded cameras); Lidar sensors for RPAS; Flash Lidar Time of Flight Camera Sensors; Flash Lidar Time of Flight Senor operation principle; Thermal vision cameras: Thermal vision cameras working principles; Thermal vision cameras for RPAS);

5) Artificial intelligence based software and hardware: Machine learning; Artificial Neural Networks; Convolutional neural networks;

6) Object detection and tracking: Drones with single object tracking features; Dual spectrum sensors with advanced imaging features and deep learning based object recognition (Overlay, Image stabilization, On the sensor multiple object detection, recognition, and tracking, Object geolocation and geographical metadata, System diagram);

7) Software packages for RPAS (Flight simulators, GIS software, Software for mission planning and control, Orthoimages 3D image processing);

8) Mission planning (Preparation for the mission using RPAS, Airframe capabilities, flight time, Flight time and distance calculation, Communication between ground control station and RPA, General mission restrictions, Weather conditions);

9) Safety requirements for using RPAS.

The assessment of the course included tests of low-cost RPA systems in real-world border control scenarios and technical Specifications of the RPAS used in the tests: Task: "PATROL" (Mission conditions, Goal, environment, test progress, Flight images); Task: „TRACKINGFOLLOWING" (Mission conditions, Goal, environment, test progress, Observations from the mission by comparing RPAS results); Task: „SEARCH" (Mission conditions, Goal, environment, test progress, Observations from the mission by comparing RPAS results); Task: "SUPERVISION" (Goal, environment, progress, Mission conditions, Observations from the mission by comparing RPAS results).

The job competences acquired by the learners after accomplishing the course:

- the learners will have a knowledge or understanding of a limited range of national, EU and international legislation, policies and procedures of using RPAS for border protection;

- patrol and border surveillance methods, tactics and techniques necessary to effectively use RPAS in border control; 
border control;

- deployment methods of systems and technology of RPAS used for

- conduct border surveillance activities using RPAS with defined methods, tactics and techniques related to RPAS operation at all types of borders according to national and EU laws, policies, rules and procedures requirements;

- operate a specific range of RPAS while performing border surveillance tasks and provide necessary maintenance procedures checking technology and equipment and interpret results;

- recognize the value of information received from RPAS when performing border surveillance tasks as potential intelligence, gathered through overt or covert activities, and report it to the management, share accordingly whilst respecting fundamental rights;

- while performing border surveillance tasks utilizing RPAS, recognize persons in need and refer them to the competent authorities.

The learning strategy of this course is designed to utilize the blended learning approach, so the course is divided into two phases: Independent Learning Phase - ILP (16 hours) and Contact Learning Phase - CLP (40 hours).

At the beginning of the ILP all learners are requested to successfully complete the on-line learning for RPAS operators, accessible via the link in the Virtual Learning Platform (VLP).

During ILP learners are expected to dedicate at least 16 hours for independent study of learning material related to RPAS (legal documents, synopsis, videos, case studies, etc.) which can be found in Virtual Aula / Moodle platform. They also have a list of additional materials regarding the course topic such as the Internet links and references. Video materials and presentations related to the operation of RPAS are provided. The ILP is interactive and continuously facilitated by the trainers, allowing learners to clarify and ask questions to the trainers before the CLP starts. ILP must be successfully completed prior to the admission to the CLP by passing an evaluation. The ILP has to be finished by passing an online test $(25 \%)$ related to the material on the topic successfully.

The purpose of the CLP is to further strengthen the knowledge obtained in ILP and gained from the experience already achieved at learners' workplace, to develop common understanding of the standards and the procedures of RPAS operators during border surveillance. During this stage the learners will be invited to actively attend discussions, case study activities and practical tasks. Trainers will conduct practical learning sessions on topics related to RPAS using in border protection, focusing on RPAS operators' 
duties, adopting learning by doing method together with peers and trainers. To that extent feedback will be utilized in order to achieve learning goals. The training material is used in an authentic learning environment to stimulate strategic and critical thinking of learners and to enhance cooperation and team working skills through group working tasks. The CLP has 40 learning hours divided in $80 \%$ practical and $20 \%$ lectures.

After completion of the course (during formative stage of the experiment), the readiness of future RPAS operators to perform professional duties on border surveillance of both EG and CG was diagnosed according to cognitive (knowledge formation) and operational (skills and abilities formation) criteria.

The average score (As) and the integral criterion (IC) were calculated by the following formulas:

$$
\begin{gathered}
A_{c}=\frac{a_{5} \cdot 5+a_{4} \cdot 4+a_{3} \cdot 3}{a_{5}+a_{4}+a_{3}}, \\
A_{I}=\frac{a_{5}+a_{4}+a_{3}}{3},
\end{gathered}
$$

Ae $a_{5}, a_{4}, a_{3}, a_{2}$ - the number of cadets who received marks "excellent", "good" and "satisfactory", respectively.

The results of assessing the knowledge of cadets on the indicators of cognitive and operational criteria for EG and CG after the experimental application of the course are given in table 2 .

Table 2. The results of assessing the knowledge of the control group cadets by the indicators of cognitive and operational criteria after the experimental course $(n=48)$

\begin{tabular}{l|c|l|c|l|c|l|c}
\hline Marks & \multicolumn{2}{|c|}{ Excellent } & \multicolumn{2}{c|}{ Good } & \multicolumn{2}{c|}{ Satisfactory } & $\begin{array}{c}\text { Average } \\
\text { score }\end{array}$ \\
\hline Criterion & Quant. & $\mathbf{\%}$ & Quant. & $\mathbf{\%}$ & Quant. & $\mathbf{\%}$ & \\
\hline Cognitive & 5,00 & 10,00 & 23,00 & 46,00 & 22,00 & 44,00 & 3,66 \\
\hline Operational & 10,00 & 20,00 & 30,00 & 60,00 & 10,00 & 20,00 & 4,00 \\
\hline Integral & 7,50 & 15,00 & 26,50 & 53,00 & 16,00 & 32,00 & 3,83 \\
\hline
\end{tabular}


Table 3. The results of assessing the knowledge of the experimental group cadets by the indicators of cognitive and operational criteria after the experimental course $(\mathrm{n}=51)$

\begin{tabular}{|c|c|c|c|c|c|c|c|}
\hline Marks & \multicolumn{2}{|c|}{ Excellent } & \multicolumn{2}{|c|}{ Good } & \multicolumn{2}{|c|}{ Satisfactory } & \multirow{2}{*}{$\begin{array}{c}\text { Average } \\
\text { score }\end{array}$} \\
\hline Criterion & Quant. & $\%$ & Quant. & $\%$ & Quant. & $\%$ & \\
\hline Cognitive & 10,00 & 19,60 & 37,00 & 72,55 & 4,00 & 7,85 & 4,12 \\
\hline Operational & 17,00 & 33,33 & 32,00 & 62,74 & 2,00 & 3,92 & 4,29 \\
\hline Integral & 13,50 & 26,47 & 34,50 & 67,64 & 3,00 & 5,89 & 4,20 \\
\hline
\end{tabular}

A comparison of the indicators of these criteria before and after the formative stage of the experiment shows that the experimental measures for the application of best European practices in the training of future RPAS operators have positively affected the quality of their training. For example, the skills formation - indicators of the operational criterion of readiness of future operators RPAS for professional activity, indicates higher scores in EG students compared to CG in terms of their skills to plan border guard operations, utilize border protection tactics, personal data protection, conduct data analysis after completing the task using special software and artificial intelligence, detect cross-border crime, recognize violators using risk profiles, carry out description of ways to commit cross-border crimes and use other risk analysis products.

\section{Discussion}

Nowadays, the researchers agree that the EU through its agencies such as European Defence Agency and Frontex is cooperating on intelligence, surveillance and reconnaissance systems of interests and also in the sphere of border surveillance (Balendr et al., 2018). Thus, RPAS for border surveillance are being studied, devised and tested in pilot projects. At the same time, the EU legislature has already paved the way for their deployment with the EUROSUR regulation, which is meant to strengthen the intelligence dimension of border surveillance, also through the deployment of drone technology in border surveillance (Marin, 2016b). Thus, implementation of common educational standards is nowadays a new tendency in border guards' education in EU.

As for the training for law-enforcement sphere, the RPAS operators in many countries have to go through the training guideline of Federation of Aviation Administration which encompasses the knowledge of aeronauticals, transportation Security Administration, operator certificate for small RPAS 
with proper investigation skills (Sharma et al., 2019). However, these guidelines may vary according to different countries and their aviation rules. Apart from this talking about the training in using RPAS, one must have the detailed knowledge of the professional sphere, in our case - in border surveillance. Also, the countries of EU have recently started implementing the programs of assessment the level of border guards' professional competence, the procedure and results of which should be considered while conducting comparative analysis of EU border guards' curricula (Balendr et al., 2019).

Therefore, the study proves that current strategy of training RPAS operators requires interoperability and harmonization of approaches and educational standards to ensure reliable protection of the EU's external borders by both the EU and Ukraine. This became possible with the introduction of the Sectoral Qualifications Framework for border guarding in the countries of the EU (Sectoral Qualifications Framework for Border Guarding, 2013), which fully complies with the European Qualifications Framework for Lifelong Learning (The European Qualifications Framework for Lifelong Learning, 2008) through which the training courses of RPAS operators were developed, which allows further development of training courses based on common standards and methods.

\section{Conclusions}

Taking into account the globalization and eurointegration tendencies, as well as current experience of the EU countries and Ukraine in developing national training courses and programs for RPAS operators training, the study proposed a common approach for training such specialists on the basis of the Sectoral Qualifications Framework in the field of border protection and Common Core Curriculum for border guards, aiming to expand the use of small RPAS for such a specific task as protection of border areas of various types (land, sea, air).

The curriculum and e-learning modules developed within the study consist of legal provisions on RPAS, contain themes of planning border guard operations, border protection tactics, personal data protection, data analysis after completing the task using special software and artificial intelligence, cross-border crime, detection and recognition of violators using risk profiles, a description of ways to commit cross-border crimes and other risk analysis products.

The results of the study were implemented at the European level using the Frontex Network of Partner Academies. The training materials 
developed during this project are used to train border guards at the regional level, the Lithuanian Border Guard School, the Center for Training in the RPAS Application and Operation of the Main Training Centre for Personnel of the State Border Guard Service of Ukraine named after Major General Ihor Momot in the framework of training programs for RPAS operators of border protection units. The results of this project helped to increase the level of the border security within the European Integrated Border Management Concept. The educational process of the future RPAS operators of the EG was based on the experimental course "RPAS Operator Course for Border Control". After completion of the course, the readiness of future RPAS operators to perform professional duties on border surveillance was diagnosed according to cognitive (knowledge formation) and operational (skills and abilities formation) criteria, according to which the integral criterion of the cadets' progress in experimental group increased to 4.20 , while in control group - only to 3.83. A comparison of the values of these criteria before and after the formative stage of the experiment shows that the experimental measures for the application of best European practices in the training of RPAS operators have positively affected the quality of their training.

\section{Acknowledgements}

We are very grateful to experts from Medinankai Border Guard School from Lithuania and Frontex Agency for their appropriate and constructive suggestions to improve this research.

\section{References}

Balendr, A., Komarnytska, O., Bloshchynskyi, I., \& Didenko, O. (2018). Informatsiyno-komunikatsiyni tekhnolohiyi z inozemnykh mov navchannya prykordonnykiv u krayinakh Yevropeyskoho Soyuzu [Information and communication technologies in foreign languages training of the border guards in the European Union Countries]. Information Technologies and Learning Tools, 67(5), 56-71. https://doi.org/10.33407/itlt.v67i5.2305

Balendr, A., Komarnytska, O., \& Bloshchynskyi, I. (2019). Ukrainian border guards interoperability assessment in the framework of common European border guard standards implementation. Advanced Education, 6(12), 35-43. https://doi.org/10.20535/2410-8286.128196

Common Core Curriculum for Border Guard Basic training in the European Union. (2012). Frontex. https://www.statewatch.org/media/documents/news/2012/mar/frontexccc-training.pdf 
Training of Remotely Piloted Aircraft Operators for Border Surveillance in ... Ivan KATERYNCHUK, et al.

Dictionary of Military and Associated Terms. (2016). United States Department of Defense. https://fas.org/irp/doddir/dod/jp1_02.pdf

Sectoral Qualifications Framework for Border Guarding. (2013). Frontex. Warsaw, Poland: Rondo ONZ 1.

Frontex Annual Activity Report (2016). European Agency for the Management of Operational Cooperation at the External Borders of the Member States of the European Union.

https://www.statewatch.org/media/documents/news/2017/aug/eufrontex-activity-report-2016.pdf

Haddal, C., \& Gertler, J. (2010). Homeland Security: Unmanned Aerial Vehicles and Border Surveillance. Congressional Research Service.

https://nsarchive2.gwu.edu/NSAEBB/NSAEBB527-Using-overheadimagery-to-track-domestic-US-targets/documents/EBB-Doc24.pdf

Interoperability Assessment Program Study. (2015). European Agency for the Management of Operational Cooperation at the External Borders of the Member States of the European Union.

https://op.europa.eu/en/publication-detail/-/publication/ae1244c0-030211e7-8a35-01aa75ed71a1

Katerynchuk, I., Rachok, R., Mul, D., \& Balender, A. (2016). Modelling of radio waves propagation and creation of radio networks using geoinformation systems. 13th International Conference on Modern Problems of Radio Engineering, Telecommunications and Computer Science (TCSET). (pp. 677-681). https://doi.org/10.1109/TCSET.2016.7452150

Katerynchuk, I., Shynkaruk, O., \& Balytskyi, I. (2018). Definition of approaches to the assessment of tactical unmanned aerial vehicles effective use in the state border guard body. TCSET-2018: 14th IEEE International Conference on Advanced Trends in Radioelectronics, Telecommunications and Computer Engineering. (pp. 1255-1259). https://doi.org/10.1109/TCSET.2018.8336422

Marin, L. (2016a). The 'metamorphosis' of the drone: challenges arising from the deployment of drone technology in border surveillance. In D. M. Bowman, E. Stokes, \& A. Rip (Eds.), Embedding New Technologies into Society. A Regulatory, Ethical and Societal Perspective (1st Edition) (pp. 1-35). Jenny Stanford Publishing.

Marin, L. (2016b). The deployment of drone technology in border surveillance, between technosecuritization and challenges to privacy and data protection. In M. Friedewald, J. P.Burgess, J. Čas, R. Bellanova, \& W. Peissl (Eds.), Surveillance, Privacy and Security. Citizens' Perspectives (1st Edition) (pp. 107-122). Routledge.

Mykytiuk, M. (2018). Rol ta mistse bespilotnykh litalnykh aparativ u zabespechenni bespeky lyudey pid chas masovykh zakhodiv [Role and the place of unmanned aerial vehicles in ensuring the safety of persons during mass events]. Scientific 
Notes of Lviv University of Business and Law. 41-47.

https://nzlubp.org.ua/index.phbp/journal/article/view/33

NATO STANAG 4670 (Edition 3) Guidance for the Training of Unmanned Aircraft

Systems (UAS) Operators. (2014). NATO Standardization Agency.

https://standards.globalspec.com/std/14246887/STANAG\%204670

Regulation (EU) 2019/1896 of the European Parliament and of the Council. (2019).

European Border and Coast Guard. https://eur-lex.europa.eu/legalcontent/EN/TXT/PDF/?uri=CELEX:32019R1896\&rid=2

Sharma, B., Chandra, G., \& Mishra, V. (2019). Comparative Analysis and Implication of UAV and AI in Forensic Investigations. Amity International Conference on Artificial Intelligence (AICAI). 824-827. https://doi.org/10.1109/AICAI.2019.8701407

The European Qualifications Framework for Lifelong Learning (EQF). (2018).

Luxembourg: Publications Office of the European Union.

http://ecompetences.eu/wp-

content/uploads/2013/11/EQF broch 2008 en.pdf 